\title{
ENDOVASCULAR TECHNIQUES FOR PLACEMENT OF LONG-TERM CHEMOTHERAPY CATHETERS
}

Guilherme Yazbek, Antonio Eduardo Zerati, Luiz Caetano Malavolta, Kenji Nishinari and Nelson Wolosker

YAZBEK G et al. - Endovascular techniques for placement of long-term chemotherapy catheters. Rev. Hosp. Clín. Fac. Med. S. Paulo 58(4):215-218, 2003.

PURPOSE: To analyze the results from using endovascular techniques to place long-term chemotherapy catheters when advancing the catheter using the external jugular vein is difficult due to obstructions or kinking.

METHODS: Between July 1997 and August 2000, 320 long-term chemotherapy catheters were placed, and in 220 cases the external jugular vein was used as the primary venous approach. In 18 of these patients, correct positioning was not achieved and several endovascular techniques were then utilized to overcome these obstacles, including manipulation of a J-wire with a moveable core, venography, and the exchange wire technique.

RESULTS: In $94.5 \%$ of the patients with difficulties in obtaining the correct positioning, we were able to advance the long-term catheter to the desired position with the assistance of endovascular techniques.

CONCLUSIONS: Venography and endovascular guidance techniques are useful for the placement of long-term catheters in the external jugular vein.

DESCRIPTORS: Endovascular techniques. External jugular vein. Guide wire. Long-term chemotherapy catheter. Stenosis and kinking.

Dissection of the external jugular vein (EJV) is the most frequently used venous approach for placing long-term chemotherapy catheters in our hospital. This procedure is safer than percutaneous puncture of the internal jugular (IJV) or subclavian veins (SCV), which is associated with potential complications that are well documented in the medical literature ${ }^{1-3}$. Although the EJV does not provide a straight path to the right atrium, as does the IJV or SCV, we have had no complications and the success rate is high.

In the majority of patients, catheters placed through the EJV advance easily to the central position at the first attempt ${ }^{4,5}$. In some cases, however, difficulties have arisen in obtaining proper placement of the catheter due to anatomical variations in veins that may be encountered (venous valves, lateral direction of EJV, presence of a plexus under the clavicle, stenosis, occlusions, kinking, and other anatomical abnormalities $)^{6,7}$. Such difficulties have not been well documented in the literature. Endovascular techniques may be a useful aid for avoiding the need to change the venous approach for advancing the catheter tip through the EJV to the central position 7 . In the present study, we have analyzed the results from using endovascular techniques to place long-term catheters.

From the Vascular Surgery Department, Hospital do Câncer, Fundação AC Camargo - São Paulo/SP, Brazil. Received for publication on February 20, 2003.

\section{MATERIAL AND METHODS}

Between July 1997 and August 2000, our team placed 320 long-term chemotherapy catheters. In 220 cases (69\%), a good EJV was identified in the physical examination, and this was the reason why this vessel was chosen as the primary venous approach. In 18 $(8.1 \%)$ of these patients, correct positioning of the catheter was not achieved at the initial attempt. In order to avoid the need to change the initial approach and the associated risk of puncture-related complications ${ }^{1-3}$, venograms using iodine contrast were made under fluoroscopy through the catheter itself. In this way we diagnosed any venous anatomical variations or obstructions (asymptomatic venous thrombosis or stenosis), and we 
were able to choose the best strategy for overcoming them. If we did not find any possibility of overcoming the abnormalities, we continued the procedure using endovascular techniques.

\section{ENDOVASCULAR TECHNIQUES}

The first endovascular technique utilized for repositioning catheters was the manipulation of a J-wire with a moveable core $^{7,8}$. This technique allows the operator to vary the length of the flexible part of the tip. After withdrawal of the moveable core, the guide wire can then be advanced.

As the tip of the wire collides with the impediment, the body of the wire progressively forms a loop, bypassing the venous stenosis or kink ${ }^{9}$.

The catheter can be slid over the protruding portion of the loop, and the guide wire withdrawn, leaving the catheter tip distal to the obstacle from where it can then be easily advanced towards the junction of the superior vena cava and the right atrium.

Another option for placing the catheter when the preceding approach was not feasible was the use of the exchange wire technique. A catheter with a preformed curve is placed just prior to the angulation or stenosis that prevents further progression. The open end of this angled tip is placed just facing the aperture through which the catheter is to eventually pass, thereby allowing the operator to coax the end of a long exchange guide wire through the orifice and through the bend. The curved catheter can then be removed, leaving behind the wire, over which the desired catheter can subsequently be easily guided to the desired final position.

\section{RESULTS}

Venograms performed on the patients for whom the initial attempt at positioning the catheter had failed showed that in 13 cases $(72 \%)$ the difficulty was due to sharp angulation at the distal end of the EJV. In these cases, the preferential course was for the catheter to drift away to the contralateral brachiocephalic vein, ipsilateral internal jugular vein, or even into other collateral veins (Fig. 1), instead of into the SCV. Stenosis was present in 4 cases (22\%) (Fig. 2), and only 1 total obstruction of the EJV was observed $(6 \%)$. In the case in which total occlusion of the EJV was present, the venous access was changed to poste- rior puncture of the ipsilateral IJV, using the same cut-down incision, and the catheter tip was then positioned with no other difficulties. In all of the remaining 17 cases $(94.5 \%)$, endovascular techniques were performed successfully, and the catheter was placed properly into the desired vessel with no sign of kinking (Figs. 3 and 4).

\section{DISCUSSION}

The EJV is the most important vein providing blood return from the face and the scalp. It is formed close to the parotid gland from the union of the auricular and retromandibular veins. It descends posteriorly to cross the sternocleidomastoid muscle; then it crosses through the fascia of the posterior triangle of the neck, and ends in the jugular-subclavian confluence or in the subclavian vein. The EJV is covered anteriorly by the platysma muscle. Its main branches are the occipital vein, the transverse cervical vein, the anterior jugular vein, suprascapular vein, and rarely, the cephalic vein. Usually it has 2 competent valves that prevent venous reflux ${ }^{10,11}$. In some cases, these valves are incompetent such that the vein fills during

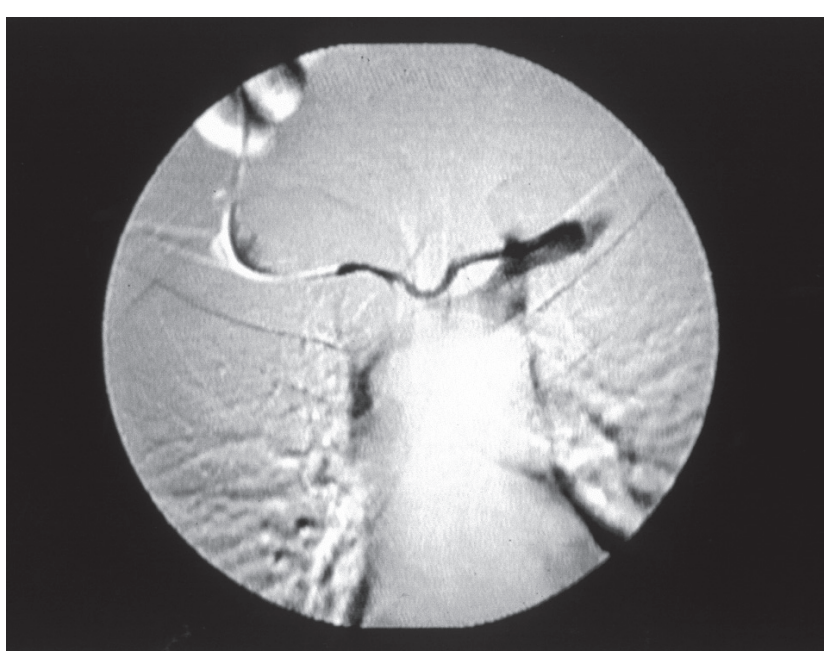

Figure 1 - Patient 1- Catheter progression into the contralateral collateral vein using the right external jugular vein approach.

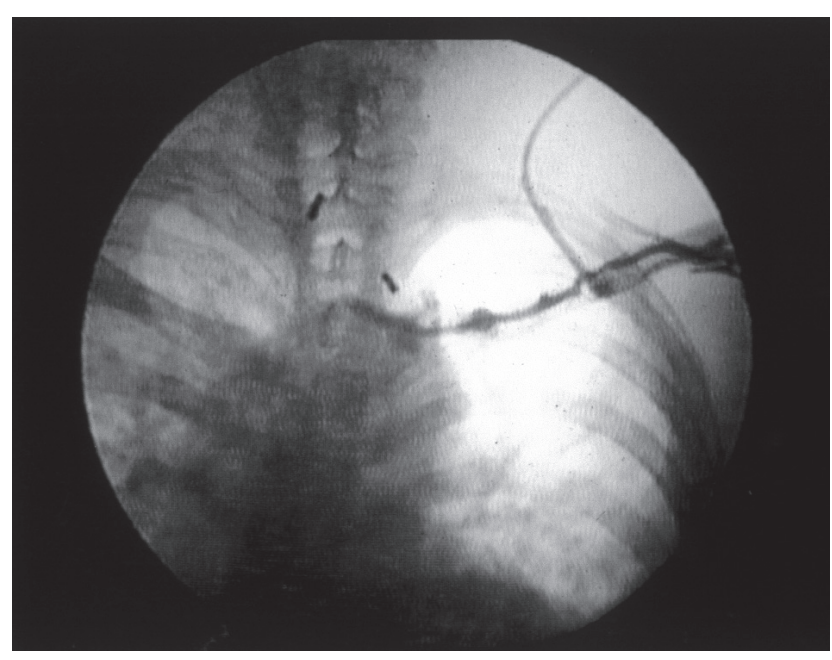

Figure 2 - Patient 2- Frustrated attempt at placing the catheter using the left external jugular vein, because of stenosis of the left subclavian vein. 


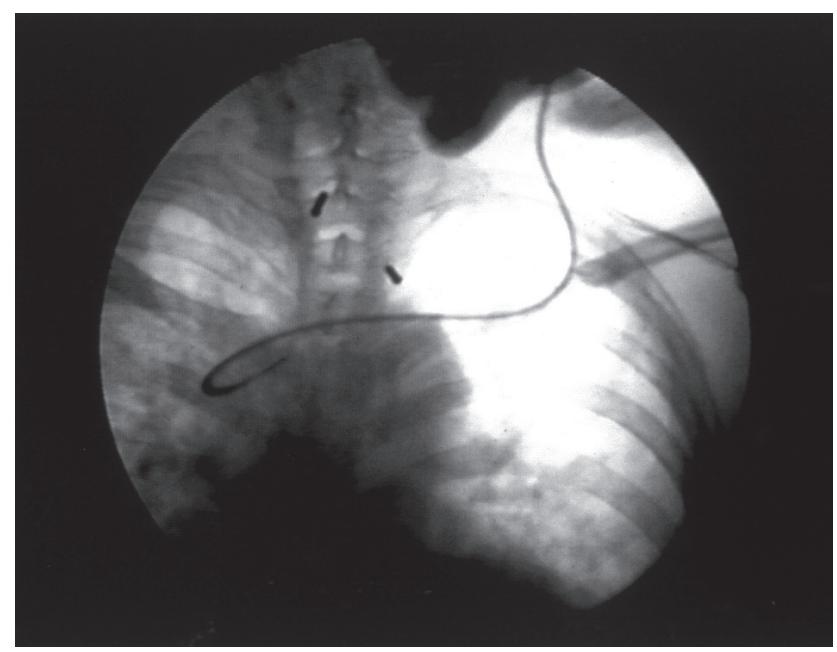

Figure 3 - Patient 1- Correct catheter tip positioning using endovascular techniques (guide wire).

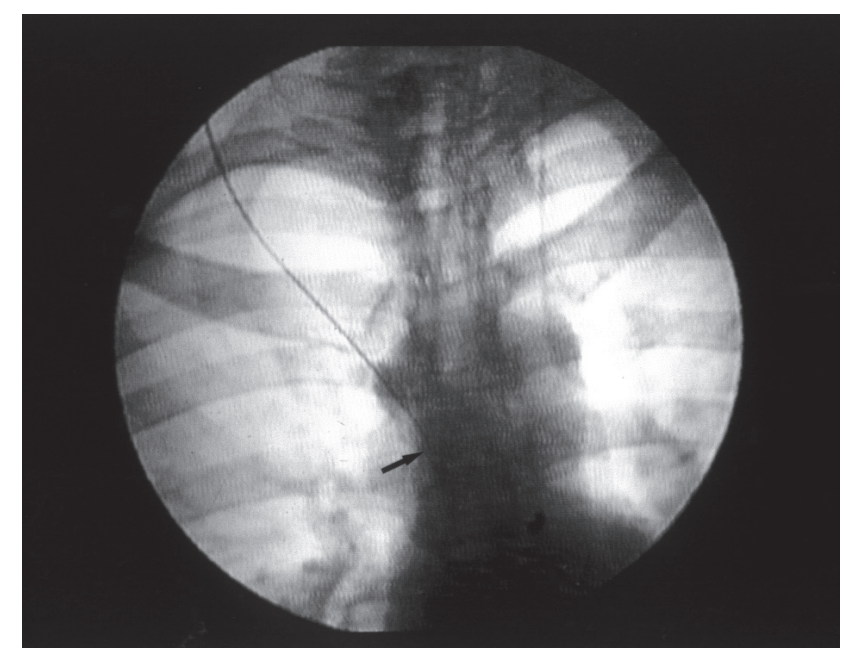

Figure 4 - Patient 2- Correct catheter tip positioning using endovascular techniques (guide wire and catheter with a preformed curve). the Valsalva maneuver, and this allows the physician to find and dissect this vein more easily.

The average diameter of the EJV is $9.3 \mathrm{~mm}$, and it has an inversely proportional relationship with the size of the $\mathrm{IJV}^{12}$. This is one of the reasons we prefer to dissect it when it is visible. In most patients, it is visible because it is superficial, and this allows the placement of long-term venous catheters.

In our patients, $69 \%$ had a visible EJV with a diameter large enough to accommodate an intravascular catheter. This vein was therefore chosen as the site for catheter placement by cutdown. Our group has preferred this technique because it appears to minimize the risk, however small, of complications related to percutaneous access. In the other $31 \%$ of the patients, where the EJV was not visible, other venous approaches were used for placement of the central venous catheter, including cut-down of the IJV in $18 \%$ of the cases, percutaneous puncture of the IJV in $11 \%$, puncture of the $\mathrm{SCV}$ in $1 \%$, and puncture of the femoral vein or cut-down of the saphenous vein in $1 \%$ of the cases.

The vast majority $(81 \%)$ of the long-term catheters placed in these patients were totally implantable vascular access devices. The remaining 19\% were partially implantable ones. The type of catheter was determined by the patient's physician on the basis of the treatment plan.

In the majority of the patients (91.9\%), catheters placed through the EJV advanced easily to the desired position at the first attempt. In the remaining patients $(8.1 \%)$, for whom this initial attempt was not successful, the use of new technology (venograms during the surgery using iodine contrast made under fluoroscopy) allowed precise diagnosis of the obstacle. Recent progress in the development of endovascular techniques allowed the guidance of the catheter into the proper infusion site in all but one of these 18 patients $(94.5 \%)$. The employment of these newer technical resources helped avoid the need for a change in the original access route.

\section{CONCLUSION}

When difficulties arise in placing a long-term central venous access from the EJV, fluoroscopic venography and endovascular guidance techniques should be used prior to using another route.

\section{RESUMO}

YAZBEK G e col. - Técnicas endovasculares para colocação de cateteres de longa permanência para quimioterapia. Rev. Hosp. Clín. Fac. Med. S. Paulo 58(4):215-218, 2003.
OBJETIVO: Analisar os resultados da utilização de técnicas endovasculares na colocação de cateteres de longa permanência para quimioterapia quando a progressão do cateter através da veia jugular externa é dificultada devido a obstruções ou tortuosidades.

MÉTODOS: Entre Junho de 1997 e Agosto de 2000, foram colocados 320 cateteres de longa permanência para quimioterapia, e, em 220 casos a veia jugular externa foi utilizada como 
acesso venoso primário. Em 18 desses pacientes, o correto posicionamento não foi conseguido sendo então utilizadas várias técnicas endovasculares para superar os obstáculos incluindo o uso de fio guia com ponta em J, flebografia e troca de cateteres.

RESULTADOS: Em 94,5\% dos pa- cientes com dificuldades para obtermos o correto posicionamento, foi conseguida a progressão do cateter de longa permanência até o posicionamento desejado com a assistência de técnicas endovasculares.

CONCLUSÃO: A Flebografia e a técnica endovascular são úteis para a colocação de cateteres de longa permanência através da veia jugular externa

DESCRITORES: Técnica endovascular. Veia jugular externa. Fio guia. Cateteres de longa permanência para quimioterapia. Estenose e tortuosidade.

\section{REFERENCES}

1. BROADWATER JR, HENDERSON MA, BELL JL et al. Outpatient percutaneous central venous access in cancer patients. Am J Surg 1990; 160:676-80.

2. RAY S, STACEY R, IMRIE J et al. - A review of 560 Hickman catheter insertions. Anaesthesia 1996; 51:981-5.

3. THOMPSON WR, ALEXANDER HR, MARTIN AJ et al. Percutaneous subclavian catheterization for prolonged systemic chemotherapy. J Surg Oncol 1985; 29:184-6.

4. SALEMI S, SPARACIA B, COSTA R et al. - Catheterization of the subclavian vein through the cannulation of the external jugular vein. Our experience. Minerva Anestesiol 1998; 64(12):5636.

5. SEGURA-VASI AM, SUELTO MD, BOUDREAUX AM - External jugular vein cannulation for central venous access (letter). Anesth Analg 1999; 88(3):692-3.

6. SPARKS CJ, MCSKIMMING I, GEORGE L - Shoulder manipulation to facilitate central vein catheterization from the external jugular vein. Anaesth Intensive Care 1991; 19(4):567-8.
7. BYTH PL - Evaluation of the technique of central venous catheterization via the external jugular vein using the J-wire. Anaesth Intensive Care 1985; 13(2):131-3.

8. BLITT CD, WRIGHT WA, PETTY WC et al. - Central venous catheterization via the external jugular vein: A technique employing the J-wire. JAMA 1974; 229:817-8.

9. BLITT CD, CARLSON GL, WRIGHT WA et al. - J-wire versus straight wire for central venous system cannulation via the external jugular vein. Anesth Analg 1982; 61:536-7.

10. DESLAUGIERS B, VAYSSE P, COMBES JM et al. - Contribution to study of tributaries and termination of the external jugular vein. Surg Radiol Anat 1994; 16(2):173-7.

11. TESTUT L, LATAJET A - Sistema de las venas yugulares externas y anteriores o venas superficiales. In: TESTUT L, LATAJET A - Tratado de Anatomía Humana. Barcelona, Salvat, 1951. p. 476 .

12. STICKLE BR, MCFARLANE H - Prediction of a small internal jugular vein by external jugular vein diameter. Anaesthesia 1997;52(3):220-2. 